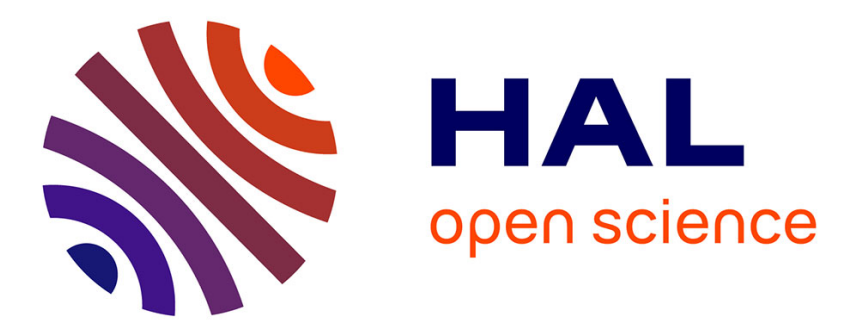

\title{
EU-Russia trading relations: the challenges of a new gas architecture
}

Catherine Locatelli

\section{To cite this version:}

Catherine Locatelli. EU-Russia trading relations: the challenges of a new gas architecture. European Journal of Law and Economics, 2015, 39 (2), pp.313-329. 10.1007/s10657-013-9423-y . hal-01131203

\section{HAL Id: hal-01131203 \\ https://hal.univ-grenoble-alpes.fr/hal-01131203}

Submitted on 13 Mar 2015

HAL is a multi-disciplinary open access archive for the deposit and dissemination of scientific research documents, whether they are published or not. The documents may come from teaching and research institutions in France or abroad, or from public or private research centers.
L'archive ouverte pluridisciplinaire HAL, est destinée au dépôt et à la diffusion de documents scientifiques de niveau recherche, publiés ou non, émanant des établissements d'enseignement et de recherche français ou étrangers, des laboratoires publics ou privés. 


\section{ÉCONOMIE DU DÉVELOPPEMENT DURABLE ET DE L'ÉNERGIE}

\section{EU-Russia trading relations \\ The challenges of a new gas architecture}

\section{Catherine Locatelli}

June 2013

Cahier de recherche EDDEN $n^{\circ} 7 / 2013$ 



\title{
EU-Russia trading relations: the challenges of a new gas architecture
}

\section{(Revision)}

Catherine Locatelli

EDDEN, UPMF, CNRS - BP 47, 38040 Grenoble cedex 9, France

Email: catherine.locatelli@upmf-grenoble.fr

June 2013

\begin{abstract}
Gas security is a key factor in the European Union's energy policy. Contractual relations based on long-term contracts during the 1970s and 1980s led to relative stability in energy trade between the EU and its gas suppliers. But since the mid-1990s, the process of opening up the EU's gas industries to competition and the desire to create a single gas market has led to an in-depth reorganization of the sector. The EU now intends to redefine the way in which it manages its relations with its main suppliers, such as Russia, by attempting to impose a model based on competition, unbundling of network industries and privatization. Russia does not intend to implement this "EU model" in its gas sector, despite the big changes taking place in its domestic market. An approach based on the preferential use of state instruments conflicts with the multilateralism and principles of competition upheld by the EU. The EU's normative power is thus in contradiction with the institutional environment of the Russian energy sector. It is therefore unlikely that energy relations between the EU and Russia will be structured solely on standards stemming from international rules and institutions.
\end{abstract}

Keywords: natural gas market, energy security, European Union JEL: D23, D86, Q34 
The energy policy of the European Union has to a large degree been focused on structuring its internal market, with two main objectives: first, to liberalize network industries (electricity and gas) - with the purpose of opening up the markets to competition - and, second, to create a single energy market to replace the twenty-seven national markets. While this approach might work in the electricity sector, reform is a more complex matter where gas is concerned, not least because of the extra dimension of the EU's relations with its gas suppliers. The expected rise in gas imports over the long term as well as an increasing number of uncertainties mean that the EU must pay particular attention to the problem of dependence, and consequently of supply security. The risks involved include the volatility of oil prices, increased state involvement in the hydrocarbon sector of the producing countries (oil nationalism), and instability in some of the EU's main gas supplier countries (Russia, Algeria) and transit countries (Ukraine). No real solution has yet been found as to how the EU can create a new gas architecture that will enable it to meet the objectives of a competitive internal market while maintaining stable and relatively risk-free relations with its suppliers.

The EU's reliance on external gas suppliers is not new. However, in the 1970s and 1980s, contractual relations based on long-term contracts produced relative stability in energy trading. With the liberalization of the EU's gas industries and the desire to create a single gas market, this trade pattern is being destabilized. Risks and benefits along the gas value chain are being redistributed, creating fresh uncertainties both for consumers and producers. In this changing environment, the EU is seeking to redefine its contractual relations with its main suppliers by exporting its acquis communautaires and attempting to impose an energy model based on competition, spot markets, de-integration of network industries and privatization. Today, the EU is faced with a fundamental question. Are the internal rules, standards and regulations generated by the two gas directives and reinforced by the Third Energy Package sufficient on their own to secure a stable gas supply for the EU? Can they guarantee the security of the EU's external gas supply?

The analysis presented here of the differences and conflicts between the EU and one of its main suppliers, Russia, will help shed some light on this question. We will show that while the liberalization process challenges the EU's relations with its suppliers, it does not really come up with an alternative "model" that might guarantee energy stability and security. Our aim here is to analyze the gas conflicts between the UE and Russia by viewing them as the result of the confrontation of different models that structure the natural gas industries of these two countries. The purpose is not to examine the efficiency of each model (for example by analyzing transaction costs) but to show that they have become established because of the presence of different institutional environments. It may emerge that the development of markets of a different nature and maturity require different structures of governance instead of a single market design (Correljé, 2006). This article adopts a multi-level approach as developed by new institutional economics (Williamson, 2000; Dixit, 2009). First we shall attempt to define the two gas industry organization models concerned, namely that of the EU and that of Russia. Second, we shall try to explain how the conflicts of interest that are emerging in the natural gas trading relations between the two regions are the product of the confrontation of these two different models.

\section{I-EU-Russia: two organizational "models" for the natural gas industry}

Gas trading relations between the EU and Russia can be characterized as interdependent. Since the end of the 1990s, these relations have however become established in a special 
context characterized by the confrontation of two organizational and institutional models. These "gas models" must be understood in terms of their coherence/complementarity in relation to the institutional environment in which they are integrated. Institutional coherence and complementarity are two concepts developed by neo-institutionalist theory (North 2005; Hopner 2005). According to the concept of institutional complementarity, the functioning of an institution is conditioned by interactions with other institutions (Höpner, 2005). Attention has focused on the complementarity links between the institutional environment and the choice of an appropriate governance structure. Aside from the question of efficiency ${ }^{1}$, we may consider that Russian gas reform based on de-integration of the main gas company and complete unbundling (as in the EU) has little credibility.

\subsection{Interdependence and divergent interests: security of supply versus security of demand}

While there is strong interdependence in gas trading relations between the EU and Russia, there are also a certain number of conflicts of interest. On the one hand, the EU is seeking to secure its gas supply, both in terms of volume and price, while on the other Russia is seeking to secure "gas demand" which depends not only on quantities but also on prices ${ }^{2}$.

Today, $70 \%$ of the gas consumed in the EU is imported. With the gradual depletion of gas reserves in the North Sea and the Netherlands and the expected rise in gas consumption in the EU, this figure will increase and, according to certain scenarios (Criqui et al. 2010), will reach between 80 and $96 \%$ by 2040 . However, since the share of natural gas in the energy mix of each member country is variable, the volumes imported will also vary. The biggest importers of natural gas in the EU are, in descending order, Germany, Italy, the UK, France, Spain, Portugal and Belgium. The Herfindhal-Hirschman index and the Shannon-Wiener index ${ }^{3}$ show that the EU's gas procurement sources are extremely concentrated, dominated by just a handful of suppliers who have a significant market share. Europe's energy vulnerability is thus considerable (Clastres and Locatelli 2012). But the situation varies widely with each member state. According to the Shannon-Wiener index, Central and Eastern European countries (Poland, Hungary, Romania), as well as the Baltic countries (for example Lithuania) and Finland are high on the energy vulnerability scale, given the predominance of a single supplier, Russia. On the other hand, countries such as France, Germany and Italy import significant amounts of gas but are less vulnerable because they have several suppliers, a particularly important factor in the event that a producer might interrupt supplies.

In consequence, the security and reliability of gas supply is today a central theme in the European Union's energy policy. The debate regarding the EU's gas security is essentially

\footnotetext{
1 According to E. Brousseau, P. Garrouste and E. Raynaud (2011), “(...) a competitive selection among institutional solutions does not systematically eliminate costly governance structures $(\ldots)$ ".

2. A number of more or less inclusive definitions of the concept of energy security have been proposed (Kruyt et al. 2009; Sovacool and Mukherjee 2011). The International Energy Agency (2001) gives a fairly restrictive definition that has since been widely used in the economic literature (Winzer, 2011). This concept refers to "the physical availability of supplies to satisfy demand at a given price". The definition includes a physical dimension, in other words the reliability of the source and the volumes available, as well as an economic dimension linked to prices and their volatility.

${ }^{3}$ The Herfindhal-Hirschman index attempts to measure market concentration while the Shannon-Wiener index measures the diversity of importers.
} 
focused on Russia given its share of the market. Russia supplies the EU with $40 \%$ of its gas imports. But the dependence of each individual country on Russian gas varies widely. Spain has zero dependence, while Central European countries have a dependence rate of $70 \%$, with this figure reaching $100 \%$ for the Baltic States, a consequence of trade relations that were forged by the former Soviet Union and the former Council for Mutual Economic Assistance (cf. Table 1).

Table 1: Dependence of certain EU countries on Russian gas

\begin{tabular}{|l|c|c|}
\hline Country & Volume $\mathbf{G m}^{\mathbf{3}}$ & $\begin{array}{l}\text { Gazprom's } \\
\text { market, \% }\end{array}$ \\
\hline Germany & 34.1 & 36.7 \\
\hline Austria & 5.4 & 51.0 \\
\hline Belgium & 3.3 & 15.3 \\
\hline Bulgaria & 2.5 & 100.0 \\
\hline Estonia & 0.7 & 100.0 \\
\hline Finland & 4.2 & 100.0 \\
\hline France & 8.5 & 18.2 \\
\hline Greece & 2.9 & 78.9 \\
\hline Italy & 17.1 & 24.6 \\
\hline Latvia & 1.2 & 100.0 \\
\hline Lithuania & 3.2 & 100.0 \\
\hline Hungary & 6.3 & 85.0 \\
\hline Poland & 10.3 & 86.1 \\
\hline Czech Republic & 8.2 & 57.5 \\
\hline Romania & 3.2 & 100.0 \\
\hline United Kingdom & 12.9 & 26.6 \\
\hline Sources: Cart & \\
\hline
\end{tabular}

Sources: Calculated on basis of Gazprom's Report, 2011, Moscow; BP Energy statistical review, 2011

At the same time, $70.8 \%$ of Russia's total gas exports go to the EU. Europe is Russia's largest gas export market. It also exports significant amounts to the CIS countries while gas exports to Asia are currently relatively low. But most importantly, the EU is a profitable market for Russia and its state-controlled company, especially when compared with the domestic market where most natural gas is sold at government-regulated tariffs (Boussena and Locatelli 2011). According to data published by Gazprom (2011), the average price of natural gas sold on the Russian market in 2010 was $\$ 77 / 1,000 \mathrm{~m}^{3}$ compared with a price of $\$ 244 / 1,000 \mathrm{~m}^{3}$ on the European market. The Russian economy depends on foreign currency earnings from its hydrocarbon exports (oil and gas) to balance its budget and help boost economic growth. Russsia's main objective, therefore, where the EU is concerned is to ensure the security of demand, both in terms of volume and price. (Tonje and De Jong 2007; Mansson et al. 2012). Consequently, recent developments in the European gas market, whether of an economic nature (uncertainty of EU demand) or institutional (new market liberalization regulations), are seen by Russia as a possible threat to its relations with the EU. In particular, the exporting countries feel that the supply security issues that are preoccupying importing countries must not overshadow their own interest of security of demand. Any analysis of gas security must take into account the interests of all the stakeholders, that is to say, exporters, importers and transit countries.

\subsection{The EU model: competition and de-integration}

The liberalization of EU gas markets driven by the gas directives of 1998 and 2003, then by the third energy package of 2009, implies a major organizational and institutional 
transformation of the gas industry in the EU countries. The aim of the EU reforms is two-fold: one the one hand to create a competitive market to replace hierarchical and administrative coordination mechanisms (Glachant and Perez, 2007), and, on the other, to establish a single gas market to replace the twenty-seven national markets. The process involves de-integration of national monopolies along with third-party access (TPA) in segments of an industry where transmission/distribution operates as a natural monopoly.

Liberalization will result in greater competition among suppliers and more spot market sales and short-term transactions. It may be considered that opening the European gas market to competition tends to increase risks along the gas value chain (Clingendael International Energy Programme 2008). In a more competitive European market, the distribution of volume and price risks (as well as the rent) between the producer and the consumer will also change.

\section{- System of governance: rule of law and multilateralism}

The EU has mainly based management of its relations with gas suppliers on dissemination of its acquis regarding the regulation and organization of energy markets (McGowan, 2007). The aim is to establish a common, regulatory space, governed by standards and rules guiding the behaviour of market players. The organization model exported by the acquis hinges on deintegrated network industries, associated with competitive modalities for access to hydrocarbon resources established by the principles set forth in the Energy Charter.

By diffusing the acquis in the gas producing countries (in particular Russia) the EU could enhance its gas supply security since it would be able test the liberalization process along the entire gas chain (from upstream to downstream). The coherence of its reforms would thus be strengthened. The emergence of a certain number of gas companies in Russia that could potentially export gas and thus compete on the European market would increase the liquidity of spot markets and enhance their credibility. Competition among Russian producers would provide the EU with an opportunity - albeit very specific - for diversifying its supply sources and thus ensuring its gas security. Finally, diffusion of the acquis by means of the transit protocol of the Energy Charter Treaty ${ }^{4}$ would also help improve supply security for the EU by promoting diversification of supply. This protocol could provide a legal framework for opening up Gazprom's pipeline network to foreign suppliers. If Gazprom were to adhere to the basic principle of "freedom of transit" by allowing third-party access to its transmission networks, gas companies would have the opportunity to ship gas from Central Asia to Europe, which would increase the number of suppliers on the European market.

Market institutions and the rule of law in a framework of international relations based on multilateralism are supposed to produce stability and security. They are central elements in the governance structure of the network industries competitive model put in place by the EU. This approach is in harmony with the institutions of the EU and no doubt with the incomplete nature of Europe's integration (Bressand, 2012). The visions and often divergent interests of member states in energy matters makes it difficult to create a real foreign policy regarding energy (Finon and Locatelli, 2008). In this situation, as Majone (1993) points out, the only way of achieving greater political integration would be by seeking integration through the market.

\footnotetext{
${ }^{4}$ The Energy Charter transit protocol (2000) specifies pipeline access conditions. It defines the principles for determining transit tariffs, available capacity and unauthorised taking of energy products during transit.
} 


\subsection{The Russian model: a "dual" gas market}

The governance structure must be aligned with the institutional environment. The model for the organization of the gas industry, underpinned by the imposition of the EU energy acquis, would involve complex, large-scale changes to the structure of the Russian gas sector. But such changes are ill suited to Russia's economic and institutional environment, particularly due to the inefficiency of certain institutions such as taxation, contracting and property rights (Rossiaud and Locatelli, 2009). From this point of view, the "Gazprom model", a hierarchical type of governance structure, is the organizational and institutional form that enables nonmonetary relations and low energy prices to be best managed.

\section{- Vertical integration and competition}

The Russian gas structure governance is characterized by the presence of the State financial holding Gazprom. With monopoly control over transmission and exports, the company enjoys dominant market power in Russia, accounting for $78 \%$ of gas production. Furthermore, due to the low gas prices on the domestic market, the regulatory measures governing the industry mainly concern quantities, with Gazprom and the main categories of consumers negotiating delivery quotas in the domestic market. Profits and costs are relatively minor concerns (Ahrend and Tompson, 2004). The idea of introducing a liberal governance structure such as that tried out in the oil sector (Rossiaud 2012) was the subject of recurrent debate throughout the 1990s, as can be seen from the various reform proposals. The question of the poor alignment (as defined by Brousseau et al, 2011) of a liberal governance structure with Russia's institutional environment led to the establishment of a hierarchical governance structure.

The hierarchical governance structure is consistent with the emergence of competitive fringes in specific segments of the Russian gas market. The dual market is characterized by regulated prices on the one hand and free market prices on the other (Ahrend and Tompson 2004) ${ }^{5}$. The purpose of competition is two-fold. First, it acts in a fairly conventional manner to help discipline the behaviour of Gazprom, the dominant market player. Second, the presence of competitors enables the State to reduce information asymmetry in its relations with Gazprom, which has long been seen as a State within the State. The second important feature is the strict control by the federal authorities over access to resources, for both national and international players. The third feature concerns gas exportations. Gazprom may encounter competition in its home market, but the authorities are reluctant to see it obliged to compete with other Russian companies in the European market. Gazprom should keep its monopoly of exports on European market to avoid contributing to lower prices on European spot markets and thus eroding Russia's monopoly profits on gas exports (Tarr, 2010).

\section{- System of governance: State company and bilateral relations}

The governance system in place is based essentially on State-controlled companies (or public property rights) inserted in a system of bilateral relations, which is in contradiction with the multilateralism promoted by the EU. State-controlled companies can serve as a remedy/substitute for the shortcomings of the market institutional arrangements in a rent

\footnotetext{
${ }^{5}$ Two other categories of players can be identified alongside Gazprom. In the first category are the independent producers, which are generally private companies that received some of the exploration and production licences at the time of the gas sector reform in 1992. The second category is the Russian oil companies.
} 
sector, taking into account the particular features of the Russian institutional environment. In fact, if the authorities have direct control over the public companies the State can use hierarchical coordination in order to impose its preferences regarding exploration and depletion rates. The State companies can also be an important complement to contractual relations. In particular, a public oil and gas company can help improve the way in which information is shared between the State and operators. This reduction in information asymmetry and ex post monitoring costs may be an important condition for the effectiveness of contractual arrangements. This is particularly true where fiscal instruments are concerned (Locatelli and Rossiaud, 2011a). The competition is emerging as an essential institution of the reform. From this point of view, the competition between the two main State companies, Rosneft and Gazprom, is a specificity of the Russian reform.

The second salient feature of the governance structure is related to the type of cooperation set up between State-owned companies and international oil companies. The State-owned oil and gas companies are the sole owners of exploration and production licences in the geographical areas covered by the partnership agreements. The cooperation between international oil and gas companies and State-owned companies is the principle of reciprocity known as "assets for assets" (Belyi, 2009).

Table 2: Organization models and Systems of governance

\begin{tabular}{|c|c|}
\hline$\underline{\mathbf{E U}}$ & Russia \\
\hline Competitive gas market & Dual gas market \\
\hline $\begin{array}{l}\text { - Vertical de-integration: Unbundling } \\
\text { - Third Party access } \\
\text { - Spot markets and hub }\end{array}$ & $\begin{array}{l}\text { - Hierarchical governance structure with } \\
\text { competitive fringe } \\
\text { - Vertical integration } \\
\text { - Export monopoly }\end{array}$ \\
\hline System of governance & System of governance \\
\hline -Rule of Law & - State company \\
\hline -Multilateralism & - Asset swapping and bilateral relations \\
\hline
\end{tabular}

\section{II - Conflicts between Russia and the EU: importance of the two governance structures}

The way in which the two parties seek to attain their economic objectives according to their particular organization and values has created a certain number of conflicts. They concern three main questions: the contractual relations between the gas companies, vertical integration of players, and access to hydrocarbon resources. Profound differences are emerging in the position of Russia and the EU concerning these three issues. The new architecture of the European gas market cannot afford to disregard this institutional conflict, but must on the contrary strike a balance between competition and security.

\subsection{Contractual relations: the stakes of the long-term take-or-pay contract}

The two organizational and institutional forms have important implications for the type of gas trading contracts that can be envisaged between the companies of the parties in question. The interdependence between the EU and its natural gas suppliers has been structured by a 
specific kind of contractual relation based on long-term take-or-pay contracts and their different clauses. Generally speaking, long-term contracts can be justified by the specificity of the assets involved, especially in relation to transmission. Transaction cost theory and the incomplete contract theory conclude that asset specificity can lead to hold-up problems given the potential for opportunist behaviour from the parties involved (Williamson 1985). In particular, the risk of ex post opportunism may cause the parties to underinvest. Complex institutional arrangements can help alleviate these problems (Nicita and Pagano 2004). Longterm TOP contracts fall into this category of incentives. There has been an abundance of literature on the subject of long-terms TOP contracts, especially in relation to the US natural gas industry (Creti and Villeneuve 2004; Hubbard and Weiner 1986 and 1991; Mulherin 1986). Contracts of this type were first implemented in Europe by the Netherlands in the 1960s and were characterized by their long duration (20-30 years) and by a certain number of clauses such as the take-or-pay clause. They have enabled stable mature gas supply systems to be developed in Europe and provided the guarantees needed for the development of the huge gas fields in Western Siberia, Urengoy and Yamburg (Boussena 1999). Today, they are a major source of conflict between the EU and Russia.

\section{- Long-term contracts and competition}

It is from the viewpoint of the principles of competition (anti-trust laws) advocated by the EU since its decision to liberalize its markets and in relation to market partitioning that long-term contracts are currently at the centre of a debate that is still by no means closed (Hautecloque and Glachant 2011). A few issues in particular should be highlighted. Generally speaking, long-term contracts are major barriers to the entry of potential new market players. One of the main problems is the risk of foreclosure caused by the behaviour of the dominant player. Long-term contracts thus hinder the development of the liquidity needed in spot markets (Hautecloque and Glachant 2011; Percebois 2008). A number of clauses in TOP contracts have therefore been called into question and some have now been removed. The final destination clause, the territorial restriction clause and the use restriction clause create entry barriers, partition markets, limit their size and are an encouragement to collusion among vendors and inhibit competition in the downstream sector (Nyssens et al. 2004; Hirschhausen and Neuman 2008). Other contractual provisions, such as profit-sharing mechanisms, are felt to have a similar effect since they make resale of gas economically less attractive or simply unfeasible (Nyssens and Osbone 2005). As a result, such clauses can no longer be included in natural gas supply contracts. However, the matter is still under discussion as far as LNG contracts are concerned. Central to the debate is how to find a trade-off between flexibility and opportunism in contracts (Crocker and Masten 1991).

In attempting to assess the effect of long-term contracts on its competition policy, the EU must take into account not only the structure of the market but also the types of companies involved in trading relations. The question of competition raises the problem of market concentration and implicitly that of the dominant position (and thus market power) of a single firm. From this point of view, Russia, through its state-controlled company Gazprom, is seen as a specific risk by the EU for a number of reasons. As a result of trading relations established under the former Soviet Union, Gazprom has a huge market share (and is more than a dominant player) in certain economies, for example the Baltic states, Hungary, Poland and Bulgaria. Such a market share is seen as a proxy for market power, and in the presence of long-term contracts this could lead to a certain number of anti-competitive effects (foreclosure, excessively high prices ...). Gazprom's profile - a company vertically integrated on its domestic market, with a transmission and export monopoly, majority state-ownership 
(51\%) and ambitions to gain a foothold in the downstream market in Europe - is the second factor used by the EU to justify its perception of a "Russian risk". Finally, Russian legislation limiting foreign investment in the development and production of Russian gas reserves is hampering attempts by European companies to get involved in this part of the chain and is thus adding to the perceived risks and uncertainties associated with this country (Locatelli and Rossiaud 2011b). Admittedly, one way of achieving gas supply security might indeed be through direct involvement in hydrocarbon production development.

\section{- Long-term contracts: sharing price and volume risks in an asset-specific industry}

Russia's main concern, however, is the substantial financing that is needed to invest in the renewal of Gazprom's production capacity. A way of securing such financing is to ensure that Gazprom has long-term guaranteed demand on its profitable export markets. This can be achieved through long-term TOP contracts. From a first interpretation, TOP contracts can be seen as a way of sharing the risks related to price and volumes between producer and consumer along the entire gas value chain, notably through the price indexation clause and clauses governing flexibility and minimum take-off volumes (Boussena, 1999). Where the supply side is concerned, these contracts provide incentives for players to make asset-specific investments (Nicita and Pagano 2004). The link between the take-or-pay clause and decisions to invest in production capacity is well established (Crocker and Masten 1991). TOP clauses ensure that substantial investment is made in production and transmission, and especially in export infrastructure. The producer effectively has a guarantee that the volumes produced will be sold. Where prices are concerned, indexation of natural gas prices to those of energies competing with gas in final energy consumption sources provides consumers with protection against price risks (Konoplyanik 2010). Importers have a guarantee that the price of gas will remain competitive with that of alternative energy sources, which in the 1970s and 1980s was oil. A second interpretation considers these contracts to be a mechanism for implementing incentives to improve contract performance (Masten and Crocker 1985). Finally, TOP contracts represent an opportunity to eliminate externalities such as problems of free riding

Changes to the duration of long-term contracts and to certain clauses - and even the possibility of removing some provisions - can create major uncertainties for Gazprom, who would no longer have a contractually guaranteed demand for the long term. It would instead have to compete on spot markets. Gazprom has constantly reiterated its preference for longterm TOP contracts, maintaining that they are needed to finance the considerable investment required to renew production capacity, and in particular to develop the fields in Yamal province. Until such contracts are signed with EU countries Gazprom has put its strategic investments on hold, creating uncertainties regarding the evolution of future output (Boussena and Locatelli 2011).

\subsection{Price formation: spot prices versus a hybrid pricing system}

The conflicts between the EU and Russia - and negotiations between European firms and Gazprom - hinge essentially on prices and the indexation formulas used in long-term contracts to calculate these prices. A hybrid pricing system prevails in the EU (Clingendael International Energy Programme, 2008), marked by two rationales for the formation of natural-gas prices: one based on spot markets where the price results from the confrontation of supply and demand; the other on long-term contracts. In the second case prices have traditionally been indexed to the price of crude oil or refined products. In practice the two price systems are not completely separate, but since 2008 gas prices in long-term contracts 
and on spot markets have been subject to substantial decoupling. The prices of natural gas and LNG on European spot markets have plummeted due to the over-abundance of gas caused by the economic crisis and shale gas. At the same time, the prices in TOP contracts have kept pace with the rising trend in crude oil and refined-product prices.

\section{Diagram 1: Natural gas price trends in Europe}

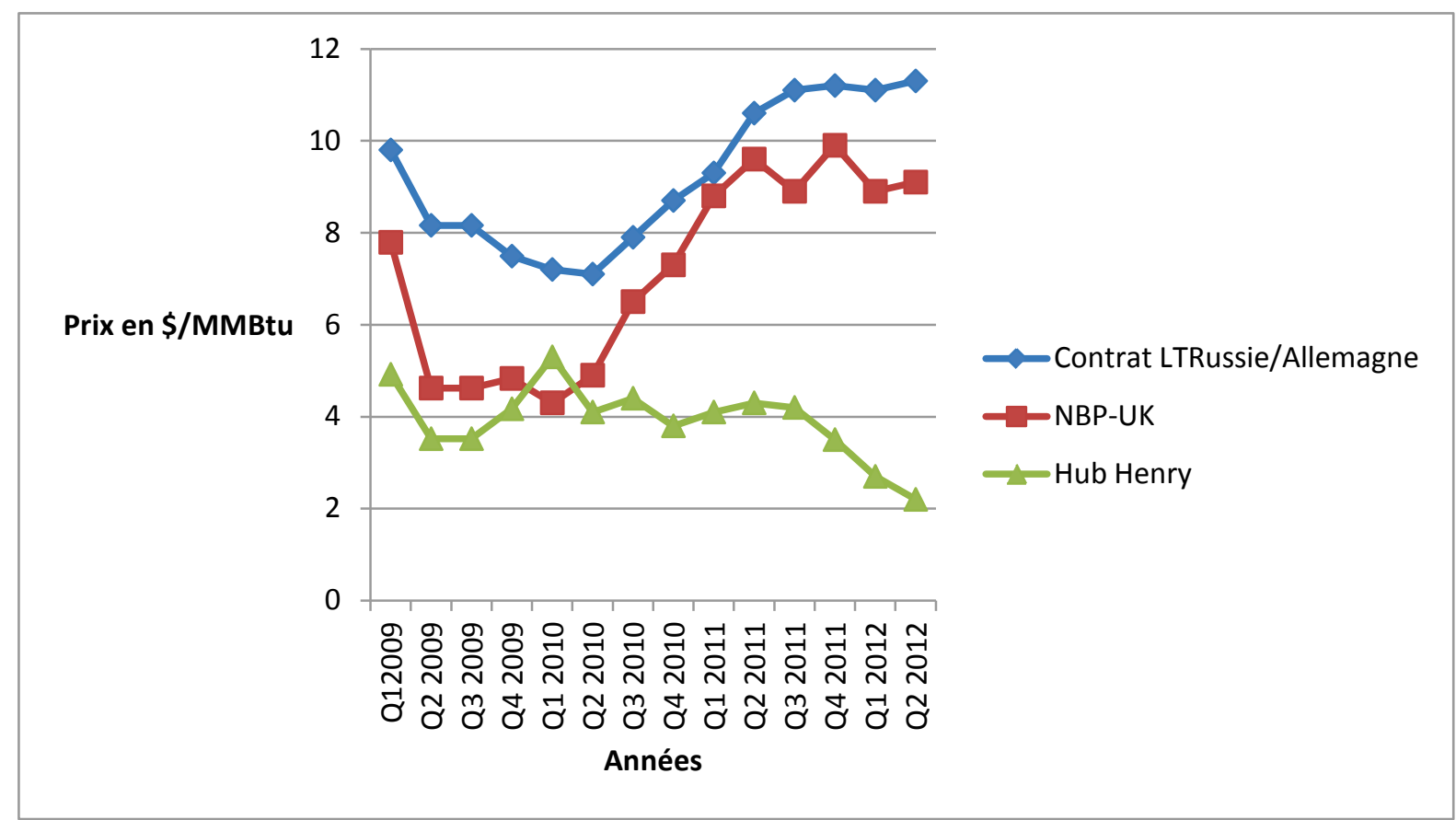

Source: Gas Matters, various years

These trends are fuelling a growing debate on the relevance of maintaining oil-indexed gas prices in long-term contracts, as illustrated by the current controversy between S. Komlev, of the Contract Structuring and Pricing Directorate at Gazprom Export, who is in favour of oilindexed pricing, and J. Stern and H. Rogers, of the Oxford Institute of Energy Studies, who oppose it (Komlev, 2013; Stern and Rogers, 2013).

\section{- Economic debate}

The main argument cited by opponents of indexation of the price of gas in long-term contracts to that of oil is that conditions in the gas market - supply and demand (spot markets) - should determine natural-gas prices. Moreover, they add, the two markets are very different, in terms of their organization, reserves, and forecast demand. Lastly, competition between the two types of energy provides less and less justification for indexing prices to oil. Gas is no longer competing with oil, but with coal and electricity. The opponents of indexation consequently advocate using the price of natural gas on spot markets as a baseline, rather than the price of oil products.

On the other hand, various reasons have been advanced to justify indexing prices to oil. Several derive from the problem of the limited liquidity ${ }^{6}$ of most EU spot markets and

\footnotetext{
${ }^{6}$ The liquidity of a gas hub can be defined as the ratio between the total volume of trade on the hub and the volume of gas consumed in the area served by the hub.
} 
consequently of the marker price. Overall, the reliability of prices decided by spot markets is one of the main constraints holding back their use in indexation formulas for long-term contracts (Frisch, 2010). For a spot price fixed at a particular hub to become a marker price, the hub must offer, among other attributes, the necessary depth, liquidity and transparency, and consequently be able to attract a significant number of market players (Heather, 2012). The marker price issue relates directly to that of the price-setting hub that might be suitable as a basis for price-indexation formulas (Stern, 2007). For the time being Britain's National Balancing Point (NBP) is the only hub with sufficient liquidity. But can it serve as a benchmark for mainland Europe, given the differences in the various gas markets?

Given the poor liquidity of spot markets there is good cause to fear manipulation of prices through coordinated agreements between dominant producers. By banking on low growth in gas production and exports, they would be able to push spot-market prices up, a strategy which could not possibly work with conventional TOP contracts (Boussena and Locatelli, 2011). The launch of the Gas Forum and the efforts of some of its members to promote the institution of an Opec-type organization for gas, in order to restrict output volume and boost prices, fits into this rationale 7 . This would give Russia, in view of its importance in supplying the EU, substantial market power. In contrast, indexing such contracts to the price of oil products makes it impossible for a single player to influence prices, and eliminates the incentive to do so. There remains the problem of volatile spot prices. One of the arguments generally put forward in favour of continued indexation to oil products is the stability this practice induces.

\section{- Position of gas companies: opposition between Gazprom and European companies}

The changes that have been taking place in the European gas market could call into question Gazprom's stance with regard to its contractual conditions, and at the very least may force the company to agree to certain amendments, including renegotiating long-term contracts in order to add greater flexibility and preserve its market shares. As is the case for all gas producers, the company must find a new balance between prices and volumes. Scope for integrating spot prices in price-indexation formulas is a key issue in negotiations between Gazprom and some of its European customers ${ }^{8}$. It will also be necessary to renegotiate the minimum quantities to be taken under the terms of the TOP contracts in light of the reduction in demand on the European markets.

Gazprom continues firmly to oppose significant changes in the indexation formula itself. But it has lost a large market share. In 2012 its gas exports to Europe fell by 5.5\% while Norway saw a rise in its export volumes. This drop in the company's sales to Europe can be blamed on its strategy of defending prices to the detriment of volumes. On average the selling price of Russian gas to Europe was $\$ 402 / 1000 \mathrm{~m}^{3}$ (that is a rise of $\left.5 \%\right)^{9}$. The company has attempted to maintain a certain level of competitiveness in relation to spot prices for natural gas by agreeing to negotiate lower prices in its long-term contracts with its principal clients, but seemingly without fundamentally changing the price indexation formula. In 2012 the

\footnotetext{
${ }^{7}$ First gas OPEC meeting. EU Energy, n 231, 23 April 2010.

${ }^{8}$ The Price Review and Price Re-opener clauses are two mechanisms that were introduced in the 1980s to increase flexibility and open the way for renegotiating prices in long-term contracts. These provisions introduced the possibility of adjusting the price formula, making them an important part of the risk-sharing arrangements between importer and exporter (Wäktare 2007; Frisch 2010).

${ }^{9}$ International Gas report, $\mathrm{n}^{\circ} 718,25$ Feb. 2013.
} 
company paid a total of $\$ 2.7$ billion to the European gas companies concerned, and this could rise to $\$ 4.7$ billion for $2013^{10}$.

\subsection{Vertical integration and access to hydrocarbon resources}

The question of vertical integration and its effects on competition is at the heart of the conflict between the EU and Russia over their gas trading relations. The EU argues that foreclosure strategies and related anti-competition practices are possible because of the absence of effective unbundling of production and transmission networks ${ }^{11}$. The vertically integrated model much favoured by Gazprom, especially at the international level, is thus at odds with the logic of ownership unbundling that the EU intends to implement to remedy these problems. The measures Gazprom intends to deploy to maintain its market share in a competitive environment hinge mainly on a strategy of downstream integration in the European market (Locatelli, 2008 ; cf. Table 2). Such integration would ensure that it can market its resources without having to compete with other gas producers in a wholesale market (Eikeland, 2007). This strategy would also enable Gazprom, in its position as an oligopoly, to reap profit in local competition for direct sales to industrial and residential customers, taking advantage of the fact that they are less sensitive to fluctuating prices. This strategy fulfils one of the priority goals of Russian energy policy: to endow Russia with large, international hydrocarbon companies, capable of competing with the world's leading majors. But according to the EU, the gas company is attempting to achieve vertical integration as part of a strategy enabling it to manipulate the competitive rationale brought about by the gas directives.

Table 3: The main stakes held by Gazprom in joint ventures with EU partners, and its main European subsidiaries

\begin{tabular}{|l|l|}
\hline Austria & Company \\
\hline Hungary & $\begin{array}{l}\text { The Russian firm will market gas directly } \\
\text { through a joint subsidiary, GWH, and Centrex } \\
\text { (in which Gazprom holds a 25\% share) }\end{array}$ \\
\hline Italy & $\begin{array}{l}\text { Acquisition of share in E.ON Foldag Storage } \\
\text { and E.ON Foldaz and in regional gas and } \\
\text { electricity suppliers as part of a deal with E.ON } \\
\text { concerning its holdings in MOL }\end{array}$ \\
\hline Poland & $\begin{array}{l}\text { Possibility of acquisition of 10\% stake in } \\
\text { Enipower with direct sales of gas for electricity } \\
\text { production }\end{array}$ \\
\hline United Kingdom & $\begin{array}{l}\text { Until 2011 a joint venture between PGNiG, of } \\
\text { Poland, and Gazprom to operate the Yamal gas } \\
\text { pipeline in Poland }\end{array}$ \\
\hline & $\begin{array}{l}\text { Acquisition of share in gas distributor Pennine } \\
\text { Natural Gas (PNG) }\end{array}$ \\
\hline Acquisition of Natural Gas Shipping Services \\
(NGSS)
\end{tabular}

\footnotetext{
${ }^{10}$ These companies are E.ON-Rurhgas (Germany), PGNiG (Poland), DONG (Denmark), ENI (Italy) and Econgas (Austria).

${ }^{11}$ Direct access to end-users would also enable a company to avoid competition in wholesale markets strategies and increase supply costs for its downstream competitors (Hansen and Percebois, 2010).
} 


\begin{tabular}{|l|l|}
\hline Estonia & $\begin{array}{l}\text { Trading, for direct sales of Russian gas in the } \\
\text { UK }\end{array}$ \\
\hline Latvia & $\begin{array}{l}\text { Purchase of a } 37.5 \% \text { share in Eesti Gaas, a } \\
\text { marketing and transmission company }\end{array}$ \\
\hline Lithuania & $\begin{array}{l}\text { Purchase of a } 34 \% \text { share in Latvijas Gaze, a } \\
\text { marketing and distribution company }\end{array}$ \\
\hline & $\begin{array}{l}\text { Purchase of a } 30 \% \text { share in Stella Vitae, a } \\
\text { transmission and distribution company }\end{array}$ \\
\hline & $\begin{array}{l}\text { Purchase of a } 37 \% \text { share in Lietuvos Dujos, a } \\
\text { marketing and transmission company }\end{array}$ \\
\hline
\end{tabular}

Some of the rules in the Third Energy Package will seek to restrict this type of adaptation through downstream integration. Such rules could significantly hinder Gazprom investments in the EU. In particular, opposition between the two parties focuses on the third-country clause, sometimes described as an anti-Gazprom clause. Coupled with ownership unbundling this clause blocks the gas company's downstream-integration strategy and opens the way for discrimination against foreign investment. These rules make it impossible for a foreign producer and supplier such as Russia to hold a majority share in EU transmission networks or to act as a Transmission System Operator in a member state (Willems et al. 2010) ${ }^{12}$.

\section{- $\quad$ The question concerning access to hydrocarbon resources}

This debate on vertical integration can be extended to the crucial question of access to the hydrocarbon resources of the producing countries, more specifically those of Russia. The EU and Russian models differ with regard to how this access can be achieved. Gaining access to resources in producing countries is the strategic objective of the Energy Charter. This multilateral investment treaty (Wälde, 2008) guarantees the possibility for European gas companies to invest in the development of hydrocarbon resources of producers (European Commission, 2010). The Energy Charter offers guarantees for international investments and imposes non-discriminatory competitive conditions regarding access to hydrocarbon resources, as well as incorporation of certain WTO clauses, such as the most favoured nation clause (Haghighi, 2007). The principle of State sovereignty over natural resources is not as such called into question by the Charter. However, the rules pertaining to non discrimination are not without repercussions.

There is no law against access by foreign investors to Russia's hydrocarbon resources witness the recent agreements (ExxonMobil-Rosneft, ENI-Rosneft, Statoil-Rosneft and TotalGazprom). But the modalities of such access - involvement of international investors through a joint venture with a state-owned company and asset swaps - do not comply with the competitive rationale upheld by the EU. They allow access to resources through bilateral relations between gas or oil companies, with the support or even involvement of states. This kind of policy based on reciprocity implemented by Russia with certain European states (Germany, Italy, France, and even the UK), is in total contradiction with the multilateralism promoted by the EU and backed by the Energy Charter.

\footnotetext{
${ }^{12}$ Re-negotiation of the gas transit contract between Poland and Russia is an illustration of the implications of these rules. The Polish section of the Yamal gas pipeline, previously operated by EurRoPol Gaz, jointly owned by PGNiG of Poland and Gazprom, is now in the hands of the Polish operator Gaz-System.
} 
Table 4: Conflicting "values" of EU and Russia

\begin{tabular}{|c|c|c|}
\hline EU & & Russia \\
\hline & Main objective & \\
\hline \multirow[t]{3}{*}{ Ensure security of supply } & & Ensure security of demand \\
\hline & Means & \\
\hline & Contractual relations & \\
\hline \multirow[t]{2}{*}{$\begin{array}{l}\text { Short term transaction, Spot } \\
\text { transactions }\end{array}$} & & Long-term TOP contracts \\
\hline & Price & \\
\hline \multirow[t]{2}{*}{$\begin{array}{ll}\text { Spot price: } & \text { confrontation } \\
\text { Supply-Demand } & \\
\end{array}$} & & Hybrid pricing system \\
\hline & Organizational structure & \\
\hline \multirow[t]{2}{*}{ Vertical unbundling } & & $\begin{array}{l}\text { Vertical integration in the } \\
\text { downstream sector }\end{array}$ \\
\hline & $\frac{\text { Access to hydrocarbon }}{\text { resources }}$ & \\
\hline \multirow[t]{2}{*}{ Multilateral investment system } & & State control \\
\hline & EU-Russia relations & \\
\hline $\begin{array}{l}\text { Exporting of acquis } \\
\text { communautaires: to create an } \\
\text { Energy market with the } \\
\text { producers }\end{array}$ & & Bilateral relations \\
\hline
\end{tabular}

Liberalization of the EU gas industry has cast doubt on the contractual relations established between the industry and its main suppliers, at a time of growing dependence on gas imports. The EU is looking for a new gas model, defining the conditions of domestic operations based on competitive wholesale markets and stable contractual relations with foreign suppliers. Such are the conditions for European gas security. From this point of view, it seems unlikely that the EU can manage these relations with the rules and standards set forth in the two gas directives and the Third Energy Package. These rules and standards run counter to the institutional environment of some of its main incumbent suppliers, primarily Russia. The EU's economic and institutional model for gas is proving difficult to apply to this country. Renewed state control of the Russian hydrocarbon industry has put the sector back on its feet and given it new momentum, but this may be wholly at odds with the multilateral approach and competitive principles advocated by the EU Energy Charter. The challenge now is to try to work out common approaches that can satisfy the concerns and objectives of both parties.

\section{References}

Ahrend, R. \& Tompson, W. (2004). Russia's gas sector: The endless wait for reform? OECD Economics Department Working Papers, $\mathrm{n}^{\circ} 402$.

Belyi, A. (2009). Reciprocity as a factor of the energy investment regimes in the EU-Russia energy relations. Journal of World Energy Law \& Business, 2(2), 117-127.

Boussena, S. \& Locatelli, C. (2011). La sécurité, question clé des relations gazières entre l'UE et la Russie. Grenoble: LEPII-EDDEN, Working papers, $n^{\circ} 6$.

Boussena, S. (1999). New European gas market: gas strategies of other present and potential suppliers, communication at: 1999 International Conference: The role of Russian and CIS Countries in Deregulated 
Energy Markets. Moscow International Energy Club; Centre de Géopolitique des Matières Premières-Université Paris Dauphine, Paris, 6-7 December.

Bressand, A. (2012). The Changed Geopolitics of Energy and Climate and the Challenge for Europe. CIEP paper.

Brousseau, E., Garrouste, P., Raynaud, E. (2011). Institutional changes: Alternative theories and consequences for institutional design. Journal of Economic Behavior \& Organization, $\mathrm{n}^{\circ} 79$.

Clastres, C., Locatelli, C. (2012). Libéralisation et sécurité énergétique dans l'Union européenne. Succès et questions. Grenoble: LEPII-EDDEN, Working papers, $\mathrm{n}^{\circ} 15$.

Clingendael International Energy Programme, (2008). The Geopolitics of EU Gas Supply: The role of LNG in the EU Gas Market. The Hague: CIEP.

Correljé, A. (2006). Structures of European Gas Markets: A Brief note. EU Gas Markets, Workshop 10 octobre, DG Internal Policies of The Union, Brussels.

Creti, A. \& Villeneuve, B. (2004). Long term contracts and take or pay clauses in natural gas markets. Energy Studies Review, 13(1), 75-94.

Criqui, P., Mima, S. \& Locatelli, C. (2010). The future of energy in Europe and the climate-security nexus: insights from the SECURE scenarios. Communication at: SECURE (EU) Regional Stakeholders meeting, Moscow, July 2.

Crocker, K.J. \& Masten, S.E. (1991). Pretia ex Machina? Prices and Process in Long-Term Contracts. Journal of Law and Economics, 34(1), 69-99.

Dixit, A. (2009). Governance Institutions and Economic Activity. The American Economic Review, Vol. 99, $\mathrm{n}^{\circ} 1$, pp. $5-24$.

Eikeland, O. (2007). Downstream natural gas in Europe - High hopes dashed for upstream oil and gas companies. Energy Policy, 35(1), 227-237.

European Commission (2010). Energy 2020: A strategy for competitive, sustainable and secure energy. Communication from the Commission to the European Parliament, the Council, the European Economic and Social Committee and the Committee of the Regions, COM (2010) 1346, Brussels.

Finon D., Locatelli C. (2008). Russian and European gas interdependence : Could contractual trade channel geopolitics? Energy Policy, vol. 36, n¹.

Frisch, M. (2010). Current European gas pricing problems: solutions based on price review and price re-opener provisions. International energy law and policy research paper series, $\mathrm{n}^{\circ} 3$.

Glachant, J., Perez, Y. (2007). Institutional Economics and Network, Industry Deregulation Policy. Groupe Réseaux Jean Monnet, Université de Paris-Sud 11.

Haghighi, S. (2007). Energy security: the external legal relations of the European Union with major oil- and gas-supplying countries. Oxford: Hart.Hansen, J-P \& Percebois, J. (2010) Energie: Economie et politiques. Brussels: De Boeck.

Hautecloque de, A. \& Glachant, JM. (2011). Long-term contracts and competition policy in European energy markets (pp. 201-232) in Glachant, JM., Finon, D., de Hauteclocque, A. (eds).Competition, Contracts and Electricity Markets: A new perspective. Edward Elgar.

Heather, P. (2012). Continental European Gas Hubs: Are they fit for purpose?, Oxford Institute for Energy Studies, NG 63. 
Hirschhausen von, C., Neumann, A. (2008). Long-Term Contracts and Asset Specificity Revisited: An Empirical Analysis of Producer-Importer Relations in the Natural Gas Industry. Review of Industrial Organization, 32(2), $131-143$.

Hopner, M. (2005). Epilogue to "Explaining institutional complementarity": What have we learnt? Complementarity, coherence and institutional change. Socio Economic Review, (3).

Hubbard, G. \& Weiner, R. (1991). Efficient contracting and market power: evidence from the U.S. natural gas industry. Journal of Law and Economics, 34(1), 25-65.

Hubbard, G. \& Weiner, R. (1986). Regulation and Long term Contracting in US Natural Gas Markets. Journal of Industrial Economics, 35(1), 47-83.

IEA (2001). Towards a sustainable energy future. Paris: International Energy Agency.

Komlev, S. (2013). Pricing the "Invisible” Commodity. Moscow: Gazprom Export. Contract Structuring and Pricing Directorate. Discussion Paper, 11 January.

Konoplyanik, A. (2010). Evolution of gas pricing in continental Europe. Modernization of indexation formulas versus gas to gas competition, CEPMLP Working Research papers, $\mathrm{n}^{\circ}$ 2010/01.

Kruyt, B., Van Vuuren, D., de Vries, H. \& Groenenberg, H. (2009) Indicators for energy security. Energy Policy, 37(6), 2166-2181.

Locatelli, C., Rossiaud, S. (2011a).A neoinstitutionalist interpretation of the changes in the Russian oil model. Energy Policy, vol. 39, $\mathrm{n}^{\circ} 9$

Locatelli, C., Rossiaud, S. (2011b). Russia's Gas and Oil Policy: the Emerging Organizational and Institutional Framework for Regulating Access to Hydrocarbon Resources. IAEE Energy Forum, 1st Quarter, 23-26.

Locatelli, C. (2008). Gazprom's export strategies under the institutional constraint of the Russian gas market. OPEC Energy Review, XXXII(3), 246-264.

Majone, G. (1993). Deregulation or re-regulation? Regulation reform in Europe and United States. London, Pinter.

Mansson, A., Johansson, B., Nilsson, LJ. (2012). Methodologies for Characterising and Valuing Energy Security - a short critical review. $9^{\mathrm{e}}$ International Conference on the European Energy Market, Florence School of Regulation, 9-12 May 2012.

Masten, S. E. \& Crocker, K.J. (1985). Efficient adaptation in long-term contracts: take-or-pay provisions for natural gas, American Economic Review, 75(5), 1083-1093.

McGowan, F. (2007). Can the European Union's market liberalism ensure security in a time of "Economic nationalism"? Journal of Contemporary European Research, 4(2), 90-106.

Mulherin, J. (1986). Complexity in long-term contracts: an analysis of natural gas contractual provisions. Journal of Law, Economics, and Organization, 2(2), 105-117.

Nicita, A., Pagano, U. (2004) Law and economics in retrospect (on line], Siena memos and papers on law and economics, $\mathrm{n}^{\circ}$ 23/04, Universita di Siena <http://www.unisi.it/lawandeconomics/simple/023_Pagano.pdf > [consulted 26/06/2012].

North, D. (2005). "Institutions and the performance of economies over time”, in Ménard, C. \& Shirley, M. (eds). Handbook of new institutional economics, Dordrecht: Springer.

Nyssens, H., Cultreta C. \& Schnichels, D. (2004). The territorial restrictions case in the gas sector: a state of play, Competition Policy Newsletter, (1), 48-51.Nyssens, H., Osborne, L., (2005). Profit splitting mechanism in a liberalised gas market: the devil lies in the detail, Competition Policy Newsletter, (1), 25-29.

Percebois, J. (2008). The supply of natural gas in the European Union. OPEC Energy Review, XXXII(1), 33-53. 
Rossiaud, S. (2012). L'évolution de la structure de gouvernance pétrolière russe. Une interprétation en termes néo-institutionnalistes. Thèse de doctorat, Université de Grenoble.

Rossiaud, S., Locatelli, C. (2009). The obstacles in the way of stabilising the Russian oil model. Post Communist Economies, 21(4), 425-438.

Sovacool, B. \& Mukherjee, I. (2011). Conceptualizing and measuring energy security: A synthesized approach. Energy, 36(8), 5343-5355.

Stern, J., Rogers, H; (2013). The transition to hub based pricing in Continental Europe: A response to Sergei Komlev of Gazprom Export. Oxford Institute for Energy Studies, Oxford Energy Comment.

Stern, J. (2007). Is there a rational for the continuing link to oil product prices in continental European longterm gas contracts? Oxford Institute for Energy Studies, NG 19.

Talus, K. (2007). Long term agreements and security of supply-between law and politics. European Law Review, $32(4), 535-547$.

Tarr, D. (2010). Export restraints on Russian natural gas and raw timber: what are the economic impacts? World Bank Policy Research working papers, $\mathrm{n}^{\circ}$ WPS 5195.

Tonjes, C. \& De Jong, J. (2007). Perspectives on security of supply in European natural gas markets. CIEP Working Paper.

Wäktare, E. (2007). Territorial restrictions and profit sharing mechanisms in the gas sector: the Algerian case. Competition Policy Newsletter, (3), 19-21.

Wälde, T. (2008). Renegotiating acquired rights in the oil and gas industries: Industry and political cycles meet the rule of law. Journal of World Energy Law \& Business, 1(1), 55-97.

Willems, A., Sul, J. \& Benizri, Y. (2010). Unbundling as a Defence Mechanism Against Russia: Is the EU Missing the Point? (pp. 227-244) in: Talus, K. \& Fratini, P., (eds), EU-Russia energy relations, Brussels: Euroconfidential.

Williamson, O. E. (2000). The New Institutional Economics: Taking Stock, Looking Ahead. Journal of Economic Literature, Vol. XXXVIII, pp. 595-613.

Williamson, O. (1985) The economic institutions of capitalism: firms, markets, relational contracting. New York: Free Press.Winzer, C. (2011). Conceptualizing Energy Security. Cambridge Working Paper in Economics, 1151. 